\title{
KEMATANGAN KARIR REMAJA DALAM PERSPEKTIF \\ ISLAM
}

\section{Agam Anantama}

Institut Agama Islam Negeri (IAIN) Metro

Jl. Ki Hadjar Dewantara 15 A Kota Metro Lampung 34111

che_ghumz@ymail.com

\begin{abstract}
Teenage career maturity is a major problem that occurs in the world of Indonesian education today. Various theories and disciplines have been studied to prepare teenagers to have career maturity. Understanding career maturity is not only reviewed in General Science disciplines such as Psychology, because since a long time Islam has discussed a lot about the personality and maturity of adolescents that can be used as a basis in understanding career maturity in an Islamic perspective. . As much as the amount of human knowledge gained through reason cannot be separated from the heart so that there tends to be a potential for indifference in seeing psychological theories about humans that can cause fatal errors in implementing it. In the context of career maturity, individuals who choose jobs are based on satisfaction, often unresolved problem. All kinds of careers cannot be separated from Islamic values because all jobs, careers, positions are intended to serve and seek God's pleasure.
\end{abstract}

Keywoard: Career Maturity, Youth, Islam 


\section{A. PENDAHULUAN}

Dewasa ini kita menyaksikan bahwa perkembangan Ilmu Agama Islam dan Ilmu Umum sangat berkembang pesat. Jika ilmu agama konsentrasi terhadap hubungan manusia dengan Tuhan dan hubungan manusia dengan manusia dalam perspektif agama, maka ilmu umum banyak membahas tentang hubungan manusia dengan manusia dan manusia dengan alam dalam perspektif kebutuhan manusia itu sendiri.Salah satu ilmu umum yang banyak berkembang saat ini adalah Ilmu Psikologi yang dalam perkembangannya diwarnai oleh berbagai aliran, corak dan profilnya masing-masing yang pada gilirannya mempengaruhi pola pikir, tindakan dan perbuatan manusia.Psikologi sendiri adalah ilmu yang mempelajari selukbeluk kejiwaan manusia. Penyelidikan tentang gejala-gejala kejiwaan itu sendiri pada awalnya dilakukan oleh para filsuf Yunani Kuno. Pada waktu itu belum ada pembuktianpembuktian nyata dan empiris melainkan segala teori hanya dikemukanan berlandaskan argumentasi-argumentasi logis (akal) belaka.

Salah satu yang menjadi pokok pembahasan dalam ilmu psikologi adalah tentang Remaja dan segala hal yang berkaitan dengan remaja termasuk perkembangan mental dan fase transisi menuju dewasa yang juga tidak lepas dari kematangan karir dalam diri remaja dalam memilih karir dan atau profesi yang kelak akan dijalaninya.Jika kita memahami esensi dari kehidupan manusia adalah bekerja, sehingga dapat menjadikan dirinya bermanfaat juga untuk orang lain. Kerja dapat diartikan sebagai pengeluaran energi untuk kegiatan yang dibutuhkan oleh seseorang untuk mencapai tujuan tertentu. Kerja juga dapat dikategorikan dengan menggeluti suatu profesi dalam suatu sistem masyarakat. Seseorang dapat memilih profesi yang dikehendakinya sesuai dengan potensi, bakat dan minat yang dimiliki.

Kualitas ibadah tidak bisa dipisahkan dari kehidupan sosial, ekonomi, dan budaya seseorang. Pribadi muslim yang paripurna (Kaffah) merupakan kesatuan dari kualitas hubungan dengan Allah SWT (Ibadah mahdoh) dan hubungan dengan makhluk (ibadah ghoir mahdoh). Dengan demikian prestasi karir seorang ummat merupakan impelementasi paling dasar dan 
implementasi kekafahan dari panggilan ketuhanan (religious calling).

Katakanlah, "Bekerjalah kamu, maka Allah akan melihat pekerjaanmu, begitu juga Rasul-Nya dan orang-orang mukmin, dan kamu akan dikembalikan kepada (Allah) Yang Mngetahui yang gaib dan yang nyata,lalu diberitakan-Nya kepada kamu apa yang telah kamu kerjakan. (QS. 9:105). ${ }^{1}$

Ayat tersebut mengandung pengertian bahwa Allah SWT memposisikan muslim sebagai hamba dan wakil Allah (khalifah) secara bersamaan. Sebagai hamba Allah, muslim wajib tunduk dan patuh pada syariat yang bersifat normatif, bagaimana hukum mengatur pribadi muslim dalam beragama dan berkarya. Syariat normatif yang dimaksudkan adalah Al Qur'an dan Sunnah. Sebagai khalifah fil ardi, manusia dituntut mempunyai kreativitas untuk senantiasa menggapai kehidupan yang lebih sejahtera. Akal dituntut untuk lebih kreatif dalam mengemban amanah khalifah, sedangkan ketaatan lebih dominan untuk mengemban sebuah amanah sebagai abdillah.

Remaja sebagai sebuah periode perkembangan ke arah kemandirian atau independensi pribadi perlu memiliki kematangan dalam menentukan pilihan-pilihan yang dihadapi di kehidupannya. Untuk mencapai aspek perkembangan ini, remaja harus dapat menyelesaikan tugas-tugas perkembangan : 1). Menerima keadaan fisiknya dan memanfaatkan secara efektif; 2). Mencapai kemandirian emosional dari orang tua atau orang dewasa lainnya; 3). Mencapai jaminan kemandirian ekonomi; 4). Memilih dan mempersiapkan suatu pekerjaan; 5). Mempersiapkan pernikahan dan kehidupan berkeluarga; dan 6). Mengembangkan konsep dan keterampilan intelektual yang perlu bagi kompetensi sebagai warga negara ${ }^{2}$

Dalam proses mencapai kemandirian ekonomi, tentu seorang remaja dituntut untuk memiliki ketrampilan dalam memilih dan mempersiapkan suatu pekerjaan atau profesi yang merupakan suatu kebutuhan karir remaja. Untuk memenuhi kebutuhan karir remaja, perlu dilakukan pendampingan secara intensif dari tenaga professional seperti konselor dalam

1 Terjemahan Alquran, KEMENAG RI, 2017

2 Prof.DrH.Syamsu Yusuf, 2000, Psikologi Perkembangan Anak $\mathcal{E}$ Remaja, Rosdakarya, Bandung 
pemberian layanan bimbingan serta konseling, kajian kebutuhan tersebut perlu dikaitkan dengan tuntutan masa kini yang juga tidak dilepaskan dari ajaran Islam, sehinga seorang remaja dapat menentukan karirnya sesuai dengan syariat Islam.

Era layanan informasi pengetahuan mencerminkan perubahan yang saling terkait dengan aspek sosial, budaya, politik, ekonomi, pemerintahan, karir, pendidikan, pekerjaan, dan sistem kehidupan lainnya. Gerakan perubahan terus meningkat dan berdampak pada perubahan pola-pola kebutuhan dan permasalahan karir individu terutama remaja yang semakin kompleks. Kebutuhan - kebutuhan mendesak dari gerakan perubahan tersebut, seperti (1) merencanakan pendidikan yang berorientasi karir; (2) memperoleh keterampilan umum dalam cakap kerja, adaptasi kerja, dan peningkatan kerja sehingga mampu mengikuti perubahan dunia kerja setelah dewasa; (3) penekanan pentingnya nilai-nilai kerja; (4) merencanakan caracara menyibukkan diri dalam pekerjaan sebagai bagian dari keseluruhan perkembangan karir; dan (5) membutuhkan informasi karir secara cepat, akurat, mudah, dan inovatif sehingga memiliki orientasi karir yang mantap ${ }^{3}$.

\section{B. REMAJA DAN MASALAH YANG DIHADAPI}

Remaja adalah sebuah periode perkembangan ke arah kemandirian atau independensi pribadi yang mana perlu memiliki kematangan dalam berpikir dan bertindak agar memudahkan mereka menentukan masa depannya. Masa remaja terbagi menjadi dua bagian, yaitu remaja awal dan akhir. terdapat batasan masa remaja berdasarkan usia kronologis, yaitu antara 13 hingga 18 tahun. Batasan usia tersebut adalah batasan tradisional yang sering dipakai secara umum, sedangkan aliran kontemporer membatasi usia remaja antara 11 hingga 22 tahun. Secara lebih detail dipaparkan bahwa usia remaja memiliki batasan usia sekitar 11-12 sampai dengan 15-16 tahun untuk remaja awal dan remaja akhir sekitar 15-16 sampai dengan18-21 tahun. ${ }^{4}$

${ }^{3}$ Hyot and Wickwire, 2001, "Knowledgeinformation - Service Era Changes in Work and Education and the Changing Role of the School Counselor in Career Education", London

4 Elizabeth B.Hurlock, , Psikologi Remaja, Mc Graw-Hill Kogakusha, Tokyo 1973 hal 79 
Perubahan sosial seperti adanya kecenderungan pada anak-anak meunju masa remaja untuk berperilaku sebagaimana yang ditunjukan remaja membuat penganut aliran kontemporer memasukan mereka dalam kategori remaja. Banyak permasalahan yang muncul pada masa-masa remaja ini. Masalah yang umumnya dialami oleh remaja muncul sebagai akibat dari adanya perubahan fisik, masalah sosial, masalah akademik, serta karir remaja tersebut. Perubahan fisik yang terjadi umumnya menjadi sumber masalah tersendiri bagi remaja, hal ini terkait dengan perubahan biologis seperti mulai munculnya hasrat seksual yang ingin terpuaskan seiring dengan matangnya organorgan seksual. Permasalahan sosial yang terjadi pada masa remaja umumnya berkaitan dengan hubungan yang lebih akrab dengan teman sebaya baik melalui pertemanan maupun percintaan. Dalam bidang akademik, remaja juga tidak jarang mengalami berbagai permasalahan, misalnya terganggunya kegiatan belajar karena berpacaran atau kenakalan remaja, penggunaan narkoba dan terlibat persoalan sosial lainnya.

Berbagai permasalah remaja yang sangat kompleks tidak dapat dihindari juga berhubungan dengan karir. Salah satunya masalah kesiapan karir. Hal ini menjadi konsekuensi logis dari perkembangan remaja dimana terdapat tuntutan bagi remaja untuk mempersiapkan karir. Adapun tugas-tugas perkembangan remaja yaitu: (1) Mencapai hubungan baru yang lebih matang dengan teman sebaya baik pria maupun wanita, (2) Mencapai peranan sosial pria dan wanita, (3) menerima keadaan fisik diri dan menggunakannya secara efektif, dan (4) Mencapai kemandirian emosional5. Pada upaya untuk mencapai peranan sosial pria dan wanita dimana di dalamnya terkandung upaya pencapaian karir remaja.

Permasalahan karir yang terjadi pada remaja biasanya berkaitan dengan pemilihan jenis pekerjaan atau fokus menekuni profesi dimasa depan. Permasalahan ini penting untuk diperhatikan sehubungan dengan banyaknya kebingungan yang dialami remaja dalam menentukan arah karirnya. Hal yang menjadi perhatian serius adalah kebimbangan karir pada remaja akan berakibat pada tingkat kematangan perkembangan kepribadian.

5 Ibid hal 80 
Perkembangan berpikir pada remaja adalah dapat memikirkan masa depan dengan membuat perencanaan dan mengeksplorasi berbagai kemungkinan untuk mencapainya ${ }^{6}$. Sehingga remaja haru menyadari bahwa dia harus segera memilih dan mempersiapkan karir yang tepat dengan potensi dan kondisinya sehingga memudahkannya dalam melangkah masa depan. Hal ini tentunya tidak dapat dipisahkan dari faktor eksternal dari remaja tersebut terutama orang di sekitarnya yang membentuk cara pandang remaja lewat bimbingan ataupun cara lainnya.

Pentingnya peran orang tua atau orang terdekat remaja dalam membimbing dan memberikan informasi serta pengetahuan tentang pilihan-pilihan karir dalam pengembangan karir di Indonesia dikarenakan adanya beberapa fenomena. Fenomena karir tersebut antara lain: (a) tingginya angka pengangguran, (b) adanya dikotomi di masyarakat antara pekerjaan yang bergengsi dengan tidak, misalnya, masih ada anggapan pekerjaan bertani lebih rendah dari pegawai kantor sehingga mempengaruhi psikis si pekerja atau calon pekerja, (c) muncul banyak sekolah atau kursus kejuruan yang akan melahirkan tenaga kerja menengah dengan keterampilan tertentu, tetapi masih banyak yang belum memiliki kompetensi standar ketenagakeerjaan, (d) lulusan dunia pendidikan cenderung menguasai teori tapi minim dalam praktekpengalaman, (e) lulusan dunia pendidikan lebih banyak dibekali dengan komptensi yang sifatnya hard skill (academic skill dan vocational skill berupa pengetahuan dan keterampilan), tapi lemah dalam pembinaan kompetensi soft skill (personal skill dan social skill antara lain: kecakapan dalam mengenal diri sendiri, percaya diri, berpikir rasional dan kritis, tanggung jawab, disiplin, kemauan kerja prestatif, jujur, keterampilan bekerjasama, nilainilai yang harus dianut dalam bekerja, kemampuan beradapatasi dengan perubahan, dsb, (f) orang-orang banyak yang bekerja sekedar memenuhi kebutuhan hidup, belum untuk kebahagiaan dan kebermanfaatan bagi kehidupan diri dan masyarakat serta lingkungan, (g) kebanyakan orang masih mengejar karir yang

${ }^{6}$ Ibid hal 35 
linier, (h) pelajar terutama siswa cenderung memilih Perguruan Tinggi belum didasarkan pada orientasi karir yang jelas ${ }^{7}$.

\section{KEMATANGAN KARIR DAN PERKEMBANGAN KEPRIBADIAN MENURUT ISLAM}

Kematangan karir merupakan aspek yang sangat penting dan perlu dimiliki remaja untuk menunjang karirnya dimasa depan. Kematangan karir adalah sikap dan kompetensi yang berperan untuk pengambilan keputusan karir.Sikap dan kompetensi tersebut mendukung penentuan keputusan karir yang tepat ${ }^{8}$. Kematangan karir juga berarti refleksi dari proses perkembangan karir individu untuk meningkatkan kapasitas dalam membuat keputusan karir. Sedangkan Crites, mendefinisikan kematangan karir individu sebagai kemampuan individu dalam membuat pilihan karir, yang meliputi penentuan keputusan karir, pilihan yang realistis dan konsisten'. Pengertian kematangan sejatinya karir jauh lebih luas daripada sekedar pemilihan sebuah pekerjaan, karena kematangan karir akan melibatkan kemampuan individu baik dalam membuat keputusan karir maupun aktivitas perencanaan karir secara sistematis. Kematangan karir mengarah pada pengenalan karir secara menyeluruh, yang diawali dengan pengenalan potensi diri, memahami lapangan kerja yang sebenarnya, merencanakan sampai dengan menentukan pilihan karir yang tepat bagi dirinya.

Pengertian kematangan karir merupakan aspek yang penting bagi individu dalam memenuhi kebutuhan akan pengetahuan dan keterampilan untuk membuat keputusan karir yang cerdas dan realistik ${ }^{10}$. Adapun keberhasilan dan kesiapan remaja atau individu untuk memenuhi tugas-tugas yang

7 Moh. Surya, Psikologi Pembelajaran dan Pengajaran, Pustaka Bani Quraisy, Jakarta 2009 hal 29

8 Hasan, B. 2006. Career Maturity of Indians Adolescents as A Function of Self Concept, Vocational Aspiration and Gender. Journal of the IndianAcademy of Applied Psychology (No. 2 Vol. 32 February 2006) hal 20

9 Levinson, Edward M et. al. 1998. Six Approaches to the Assessment of Career Maturity. Journal of Counseling and Development (Vol.76 Iss.4 Fall 1998) hal 69

10 Ibid hal 73 
terorganisir yang terdapat dalam setiap tahapan perkembangan karir disebut sebagai kematangan karir11. Kematangan karir seseorang juga dipengaruhi oleh usia dan pengalaman hidup. Kesesuaian dengan usia yang dimaksudkan dalam definisi ini, adalah berdasarkan teori Life-Span, Life-Space yaitu bahwa setiap individu pada jenjang usia tertentu mempunyai peran yang harus dijalankan sesuai dengan tahapan perkembangannya ${ }^{12}$.

Berdasarkan uraian dari beberapa pendapat tentang kematangan karir maka dapat disimpulkan bahwa kematangan karir merupakan sikap dan kompetensi individu serta kesiapan diri individu dalam menentukan keputusan karir yang ditunjang oleh faktor kognitif dan afektif dengan meningkatkan pengetahuan dan keahlian. Kematangan karir juga merupakan hubungan antara usia individu dengan tahap perkembangan karir yang mempunyai peran dalam kematangan karir yang harus dijalankan sesuai dengan tahapan perkembangannya.

Khazanah Islam memandang kematangan karir terletak pada kematangan Nafs seorang individu. Nafs dapat berarti jiwa (soul), nyawa, ruh, konasi yang berdaya syahwat dan gadhab, kepribadian, dan substansi psikofisik dalam diri manusia ${ }^{13}$. Maksud dari Nafs dalam tulisan ini adalah sebagaimana dalam pengertian yang terakhir, komponen jasad dan ruh bergabung. Nash memiliki natur gabungan antara natur jasad dan ruh. Nafs adalah potensi jasad-rohani (psikofisik) manusia yang secara inhern telah ada sejak manusia atau individu siap menerimanya.

Substansi nafs memiliki potensi gharizah. Jika potensi gharizah dikaitkan dengan substansi jasad dan ruh, dapat dibagi menjadi tiga bagian yaitu $\mathrm{Al}-\mathrm{Qalb}, \mathrm{Al}$ - $^{\prime} \mathrm{Aql}$, dan daya $\mathrm{Al}-\mathrm{Nafs}$ yang berhubungan dengan karsa atau konasi.

\section{a) Qalbu}

Qalbu (al-qalb) merupakan materi organik (al'adhuw al-madiy) yang memiliki sistem kognisi (jihaz idrkiy ma'rifiy) yang memiliki daya emosi (al-syu'ur) ${ }^{14}$.

11 Gonzalez, Manuel Alvarez. 2008. Career Maturity: A Priority for Secondary Education. Electronic Journal of Research in Educatonal Psychologi (No. 16 Vol. 6 (3). 2008). p. 749-772.

12 Ibid;

${ }^{13}$ Netty Hartati, dkk, Islam dan Psikologi, Rajawali Pers, Jakarta 2004 hal 78

14 Ibidhal 79 
Al-Ghazali secara tegas memisahkan qalbu dalam dua aspek, yaitu qalbu jasmani dan qalbu ruhani. Qalbu jasmani adalah daging sanubari yang berbentuk seperti jantung pisang yang terletak di dalam dada bagian sebelah kiri. Qalbu ini biasanya disebut jantung (heart). Sedangkan qalbu ruhani adalah sesuatu yang bersifat halus (lathif), rabbani, dan ruhani yang berhubungan dengan qalbu jasmani. Bagian ini merupakan esensi manusia

Al-Ghazali berpendapat bahwa qalbu memiliki insting yang biasa disebut dengan al-nur al-ilahiy (cahaya ketuhanan) dan al-bashirah al-bathinah (mata batin) yang memancarkan keimanan dan keyakinan ${ }^{15}$. AlZamakhsyariy menegaskan pula bahwa qalbu itu diciptakan oleh Allah Swt. Sesuai dengan fitrah asalnya dan berkecenderungan menerima kebenaran dari Nya ${ }^{16}$. Dari pandangan ini, qalbu ruhani merupakan bagian paling esensi dari nafs manusia. Qalbu ini berfungsi sebagai pemandu, pengontrol, dan pengendali struktur nafs yang lain. Apabila qalbu ini berfungsi dengan baik, maka kehidupan manusia menjadi baik dan sesuai pada fitrah aslinya, karena qalbu ini memiliki natur ilahiyah dan rabbaniyah. Natur ilahiyah merupakan natur supra kesadaran, yang dipancarkan Tuhan. Dengan natur ini maka manusia tidak sekedar mengenal lingkungan fisik dan sosialnya, melainkan juga mampu mengenal lingkungan spiritual, ketuhanan, dan keagamaan. Sehingga dapat dengan kritis dan bijak dalam menentukan pilihan hidupnya.

Dalam realitasnya, potensi qalbu tidak selamanya mrnjadi tingkah laku yang baik. Baik-buruknya sangat ditentukan oleh pilihan manusia itu sendiri. Seperti sabda Nabi Saw :

"Sesungguhnya di dalam tubuh terdapat segumpal daging. Apabila ia baik maka semua tubuh menjadi baik, tetapi apabila ia rusak maka semua tubuh menjadi

${ }^{15}$ Ibid hal 80

16 Zamakhsyariy, Op.Cit., juz I, hlm.. 295. 
rusak pula. Ingatlah bahwa ia adalah qalbu."(HR AlBukhari dari Nu'man ibn Basyir $)^{17}$

Al-Ghazali berpendapat bahwa qalbu diciptakan untuk memperoleh kebahagiaan akhirat kelak. Sedangkan kebahagiaan qalbu sangat tergantung dari ma'rifah kepada Allah Swt. Ma'rifah kepada Allah Swt sangat bergantung pada perenungan trhadap ciptaannya. Adapun pengetahuan terhadap ciptaan allah Swt hanya dapat diperoleh melalui bantuan indera manusia ${ }^{18}$. Dari uraian tersebut maka dapat kita pahami bahwa bahwa indera harus bersumber dari qalbu. Tanpa bersumber dari qalbu maka indera manusia tidak akan memperoleh daya persepsi, terutama persepsi spiritual. Daya persepsi manusia akan terwujud apabila terjadi interelasi antara daya-daya qalbiah dengan daya-daya indera. Disini kita bisa sedikit mengambil kesimpulan bahwa dalam mematangkan karir dan perkembangan karir manusia terutama remaja, maka harus memiliki daya persepsi yang kritis terhadap lingkungan sekitar dengan menyucikan qalbu lewat pendekatan kepada Allah Swt.

b) $A l-' A q l$

Secara etimologi akal memiliki arti al-imsak (menahan), al-ribath (ikatan), al-hajr (menahan), al-nahy (melarang), dan man'u (mencegah) ${ }^{19}$. Berdasarkan pengertian tersebut maka orang yang berakal (al-'aql) adalah orang yang mampu menahan dan mengikat hawa nafsunya. Jika hawa nafsunya terikat maka jiwa rasionalitasnya akan bereksistensi dengan bijak.

Akal diartikan sebagai energi yang mampu memperoleh, menyimpan, mengolah dan mengeluarkan pengetahuan. Akal mampu mengantarkan manusia pada hal substansi humanistik (zat insaniah) ${ }^{20}$ atau

17 Ibn 'Abd Allah Muhammad ibn Ismail ibn Al-Mughirah ibn Bardizbah Al Ja'fi Al-Bukhairiy Imam, Sahih Al-Bukhairiy, (Semarang: Thaha Putra, t.t), Juz I Hlm. 19.

18 Ibid;

${ }^{19}$ Ma' an Ziyadat, op.cit., Al-Raghib Al-Ashfahaniy,

${ }_{20}^{20}$ Abi Al-Baqa' Ayyub ibn musa, op.cit., hlm 618 loc.cit 
potensi fitriah yang memiliki daya pembeda antara halhal yang baik dan buruk, yang berguna maupun membahayakan. Pengertian tersebut dapat dipahami bahwa akal merupakan daya berpikir manusia dalam memperoleh pengetahuan yang bersifat rasional dan dapat menentukan eksistensi manusia.

Akal secara psikologis memiliki fungsi kognisi (daya cipta). Kognisi ialah suatu konsep umum yang mmencakup semua bentuk dari pengalaman kognisi, mencakup aktifitas mengamati, melihat, memperhatikan, memberikan pendapat/pandangan, mengasumsikan, berimanjinasi, memprediksi, berpikir kritis, mempertimbangkan, menduga dan menilai sesuatu $^{21}$.

Pengertian akal dalam penjelasan Alquran berbeda dengan qalbu. Akal dijelaskan hanya dalam bentuk kata kerja ( $\left.f^{\prime} i l\right)$ dan satupun tidak disebutkan dalam bentuk kata benda (isim). Hal ini menunjukan bahwa akal bukanlah suatu substansi (jauhar) yang bereksistensi, melainkan aktifitas substansi tertentu. Hal tersbut sependapat dengan Plato yang menyatakan bahwa jiwa rasional bertempat di kepala (otak) manusia, sehingga yang berpikir adalah akal dan bukan qalbu.

\section{c) Nafsu}

Nafsu adalah daya nafsani yang memiliki dua kekuatan yaitu kekuatan al-ghadabiyah dan al-

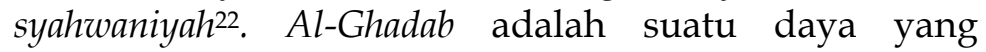
berpotensi untuk menghindari diri dari segala yang membahayakan manusia. Ghadab dalam terminologi psikoanalisis disebut dengan defense (pertahanan) atau tingkah laku yang berusaha membela atau melindungi ego terhadap kesalahan, kecemasan, dan rasa malu; perbuatan melindungi diri sendiri dan memanfaatkan atau merasionalisasikan perbuatannya sendiri. AlSyahwat adalah suatu daya yang berpotensi untuk

${ }^{21}$ J.P Chaplin, op.cit., hlm. 90.

22 Al-Ghazali, Ihya', loc.cit Abu Hamid Muhammad Al-Ghazali, Maqashid alFalasifat, editor Sulaiman Dunya, (Mesir; Dar Al-Ma'arif, t.t.), hlm. 347-348 
menginduksi diri dari segala yang menyenangkan. Syahwat dalam terminologi psiokologi dikenal dengan appetite, yaitu suatu hasrat (keinginan, birahi, hawa nafsu)," motif atau suatu impuls berdasarkan pada perubahan keadaan fisiologi.

Prinsip kerja nafsu mengikuti prinsip kenikmatan (plesure principle) dan berusaha mengumbar impulsimpuls primitifnya tersebut. Apabila impuls-impuls ini tidak dipenuhi maka akan terjadi ketegangan diri. Prinsip kerja nafsu ini memiliki kesamaan dengan prinsip kerja jiwa binatang. Binatang buas (al-subu'iyah) memiliki impuls agresif (menyerang), sedangkan binatang jinak (al-bahimiyah) memiliki impuls seksual. Oleh karena prinsip inilah maka nafsu sering disebut juga sebagai fithrah hayawaniyah.

Nafsu dalam terminologi psikologi dikenal dengan sebuah konasi (daya karsa). Konasi (kemauan) adalah bereaksi, berbuat, berusaha, berkemauan, dan berkehendak. Aspek konasi kepribadian ditandai dengan tingkah laku yang bertujuan dan impuls untuk berbuat ${ }^{23}$. Nafsu menunjukan struktur dibawah sadar dari kepribadian manusia yang jika manusia mengumbar dominasi nafsunya maka rasionalitas menjadi tumpul dan kepribadiannya tidak akan mampu bereksistensi, baik di dunia maupun di akhirat.

Melalui pemetaan diatas dapat disimpulkan bahwa struktur kejiwaan manusia (nafsani) terutama remaja bersumber dari peran-peran ruh dan jasad dengan berbagai naturnya. Tingkatan kepribadian manusia sangat tergantung kepada substansi mana yang lebih dominan menguasai dirinya. Dalam proses kematangan karir dan perkembangan karir, qalbu haruslah dapat mengontrol, mengawasi dan menjaga akal agar senantiasa mampu mendominasi nafsu sehingga dalam perkembangan diri remaja dapat menentukan pilihan dan mempersiapkan dirinya dalam karir kedepan.

${ }^{23}$ J.P Chaplin, op.cit., hllm. 101. 


\section{FAKTOR KEMATANGAN KARIR}

Shertzer dan Stone, membagi faktor-faktor yang mempengaruhi perkembangan karir menjadi dua yaitu faktor internal dan eksternal. Faktor internal yang dimiliki seseorang yang akan mempengaruhi perkembangan karirnya ialah nilai-nilai kehidupan yang diikuti, taraf inteligensi, bakat khusus yang dimiliki, minat, sifat, informasi tentang bidang-bidang pekerjaan, serta keadaan fisik ${ }^{24}$. Sedangkan faktor eksternal yang akan mempengaruhi perkembangan karir seseorang adalah meliputi masyarakat (lingkungan sosial budaya), keadaan sosial ekonomi suatu negara atau daerah, status social ekonomi keluarga, pengaruh dan ekspektasi dari keluarga besar dan inti, pendidikan, persekawanan, serta tuntutan yang melekat pada masing-masing pekerjaan.

Pakar lainnya yang mengetengahkan faktor-faktor dalam mempengaruhi perkembangan karir adalah Seligman. Menurutnya ada enam faktor yang terlibat, yaitu keluarga, masyarakat, social ekonomi, individu, serta faktor psikososial dan emosional25. Kesimpulan yang bisa dipetik dari dari dua pendapat diatas adalah bahwa faktor yang mempengaruhi kematangan karir individu dapat berasal dari faktor internal faktor yang muncul dari dalam diri) dan eksternal (faktor yang muncul dari pengaruh lingkungan) individu. Selain itu faktor lain yang juga mempengaruhi kematangan karir adalah keluarga, masyarakat, sosioekonomi, individu, serta faktor psikososial dan emosional.

Selain dua pandangan diatas, faktor kematangan karir dalam Islam adalah kemampuan seseorang dalam mengintegrasikan sistem qalbu, akal dan nafsu yang menciptakan tingkah laku. Meskipun pandangan ini sangat sederhana, namun memiliki makna yang sangat mendalam. Ketiga komponen nafsani ini berintegrasi untuk mewujudkan suatu tingkah laku atau sikap yang menjadi

${ }^{24}$ W. S Winkel \& Sri Hastuti. Bimbingan dan Konseling di Institusi Pendidikan. Yogyakarta: FKIP Universitas Sanata Dharma2005. hlm. 647.

25 Tri Muji Ingarianti. Hubungan Antara Adversity Quotient Dengan Kematangan Karir Pada Remaja. Laporan Penelitian. UMM Malang 2009 hal 210 
ukuran kematangan seseorang dalam memilih dan menekuni karir. Qalbu memiliki kecenderungan natur ruh, nafs (daya syahwat dan ghadhab) memiliki kecenderungan pada natur jasad, sedangkan akal memiliki kecenderungan antara ruh dan jasad. Dari sudut tingkatannya, kepribadian itu merupakan integrasi dari aspek supra-kesadaran (fitrah ketuhanan), kesadaran (fitrah kemanusiaan), dan pra atau bawah kesadaran (fitrah kebinatangan). Sedangkan dari fungsinya, kepribadian merupakan integrasi dari daya emosi dan kognisi yang terwujud dalam tingkah laku eksteren (berjalan, berbicara, dsb) maupun tingkah laku inheren (pikiran, perasaan,)

\section{E. INDIKATOR DAN PARAMETER KEMATANGAN KARIR}

Donald E. Super menyatakan bahwa kematangan karir remaja dapat diukur dengan indikator-indikator sebagai berikut ${ }^{26}$ :

a. Perencanaan karir (career planning). Aspek perencanaan karir merupakan aktivitas pencarian informasi dan seberapa besar keterlibatan individu dalam proses tersebut. Kondisi tersebut didukung oleh pengetahuan tentang macam-macam unsur yang ada pada setiap pekerjaan. Indikator ini adalah menyadari wawasan dan persiapan karir, memahami pertimbangan alternatif pilihan karir dan memiliki perencanaan karir dimasa depan secara matang 27.

b. Eksplorasi karir (career exploration). Merupakan kemampuan individu untuk melakukan pencarian informasi karir dari berbagai sumber karir, seperti kepada orang tua, saudara, kerabat, teman, guru bidang studi, konselor sekolah, maupun sumber lainnya. Aspek eksplorasi karir berhubungan dengan seberapa banyak informasi karir yang diperoleh remaja dari berbagi sumber tersebut. Indikator dari aspek ini adalah mengumpulkan informasi karir dari berbagai sumber

Sharf, Richard S. Applying Career Development Theory To Counseling. California: Books/Cole Publishing Company 1992 hal 29 27 Ibid hal 20 
dan memanfaatkan informasi karir yang telah diperolehnya ${ }^{28}$.

c. Pengetahuan tentang membuat keputusan karir (decision making). Aspek ini adalah kemampuan remaja dalam menggunakan pengetahuan dan pemikiran dalam membuat perencanaan karir. Konsep ini didasari pada tuntutan remaja dalam membuat keputusan karir, dengan asumsi apabila ia mengetahui bagaimana orang lain membuat keputusan karir maka diharapkan mereka juga mampu membuat keputusan karir yang tepat bagi dirinya ${ }^{29}$.

d. Pengetahuan (informasi) tentang dunia kerja (world of work information). Aspek ini terdiri dari dua komponen, yakni terkait dengan tugas perkembangan, dimana individu harus tahu minat dan kemampuan diri, mengetahui cara orang lain mempelajari hal-hal yang berkaitan dengan pekerjaan dan mengetahui alasan orang merubah pekerjaan. Komponen kedua adalah mengetahui tugas-tugas pekerjaan dalam suatu jabatan dan perilaku-perilaku dalam bekerja ${ }^{30}$.

e. Pengetahuan tentang kelompok pekerjaan yang lebih disukai (knowledge of preferred occupational group). Aspek ini adalah dimana remaja diberi kesempatan untuk memilih satu dari beberapa pilihan pekerjaan, dan kemudian ditanyai mengenai hal-hal yang berkaitan dengan pekerjaan tersebut. Mengenai persyaratan, tugas-tugas, faktor-faktor maupun alasan yang mempengaruhi pilihan pekerjaan dan mengetahui resiko-resiko dari pekerjaan yang dipilihnya. Indikator pada aspek ini adalah pemahaman mengenai tugas dari pekerjaan yang diinginkan, memahami persyaratan dari pekerjaan yang diinginkan, mengetahui faktor dan alasan yang mempengaruhi pilihan pekerjaan yang diminati dan mampu mengidentifikasi resiko-resiko yang mungkin muncul dari pekerjaan yang diminati sehingga menjadi pertimbangan bagi remaja tersebut ${ }^{31}$.

\footnotetext{
${ }^{28}$ Ibid; hal 20

${ }^{29}$ Ibid; hal 22

30 Ibid; hal 23

31 Ibid; hal 30
} 
f. Realisasi keputusan karir (realisation). Realisasi keputusan karir adalah perbandingan antara kemampuan individu dengan pilihan karir pekerjaan secara realistis. Aspek ini antara lain mendorong remaja untuk memiliki pemahaman yang baik tentang kekuatan dan kelemahan diri berhubungan dengan pekerjaan yang diinginkan, mampu melihat faktor-faktor yang mendukung dan menghambat karir yang diinginkan, mampu mengambil manfaat membuat keputusan karir yang realistis.

Individu yang memiliki kematangan karir yang baik bisa di maknai telah memiliki orientasi karir (career orientation). Orientasi karir didefinisikan sebagai akumulasi dari: 1) sikap remaja terhadap karir, 2) keterampilan dalam membuat keputusan karir, dan 3) informasi terhadap dunia kerja $^{32}$. Sikap terhadap karir terdiri dari perencanaan karir dan eksplorasi karir. Keterampilan membuat keputusan karir terdiri dari kemampuan menggunakan kemampuan dan pemikiran dalam membuat keputusan karir. Informasi karir terdiri atas memiliki informasi tentang pekerjaan tertentu dan kelompok pekerjaan yang lebih disukai.

Kesimpulan dari pendapat diatas menyatakan bahwa faktor kematangan karir individu dipengaruhi oleh aspek perencanaan karir, eksplorasi karir, pengetahuan tentang membuat keputusan, informasi tentang dunia kerja, pengetahuan tentang kelompok pekerjaan yang disukai, dan realisasi keputusan karir.

Dalam Islam, indikator seseorang yang memiliki kematangan terbagi menjadi tiga kepribadian, yaitu kepribadian ammarah, kepribadian lawwamah, dan kepribadian muthmainnah ${ }^{33}$.

\section{a) Kepribadian Ammarah (nafs al-ammarah)}

Kepribadian ammarah adalah kepribadian yang cenderung pada tabiat jasad dan hanya mengejar prinsip-prinsip kenikmatan (pleasure principle). Ia menarik qalbu manusia untuk melakukan perbuatanperbuatan yang buruk sesuai dengan naluri primitif,

32 Ibid hal 80

33 Netty Hartati, dkk, 2004, Islam dan Psikologi, Rajawali Pers, Jakarta,. Hlm. 166 
sehingga ia merupakan tempat dan sumber dari kejelekan dan tingkah laku yang tercela ${ }^{34}$. Sebagaimana firman Allah Swt :

Sesungguhnya nafsu itu selalu menyerukan pada perbuatan buruk, kecuali nafsu yang diberi rahmat oleh Tuhanku. (QS Yusuf 12;53) ${ }^{35}$

Kepribadian ammarah adalah kepribadian dibawah kesadaran manusia. Barangsiapa yang berkepribadian ini maka sesungguhnya ia tidak lagi memiliki identitas manusia karena sifat-sifat humanitasnya telah hilang. Kepribadian ammarah dapat beranjak ke kepribadian yang baik apabila ia telah diberikan rahmat oleh Allah Swt. Menaikkan kepribadian ammarah menuju kepribadian lawwamah memerlukan latihan (riyadhah) khusus untuk menekan daya nafsu dari hawa, seperti dengan berpuasa, shalat, berdoa dan sebagainya. Hal ini menjadi penting karena tingkat kematangan karir seseorang yang berkepribadian ammarah sangat labil dalam memutuskan karir kedepan karena mengedepankan nafsu.

\section{b) Kepribadian Lawwamah (nafs al-lawwamah)}

Kepribadian lawwamah adalah kepribadian seseorang yang telah memperoleh cahaya qalbu, lalu ia bangkit untuk memperbaiki kebimbangannya diantara dua pilihan. Dalam pilihannya tersebut kadang-kadang cenderung pada perbuatan buruk yang disebabkan oleh watak zhulmainah (gelap) namun kemudian ia di ingatkan oleh nur ilahi, sehingga ia mencela perbuatannya dan selanjutnya ia bertaubat dan beristighfar. Hal ini dapat dipahami karena kepribadian lawwamah berada dalam kebimbangan antara kepribadian ammarah dan kepribadian muthmainnah.

Kepribadian lawwamah merupakan kepribadian yang didominasi oleh komponen akal. Sebagai

34 Abd Al-Razzaq Al-Kalsyaniy, Mu'jam Isthilahat Al-Shufiyah, (Cairo: Dar Al-'Inad, 1992), hlm. 115

35 Terjemahan Alquran, KEMENAG RI, 2017 
komponen yang bernatur insaniah, akal mengikuti prinsip kerja rasionalitas dan realistis yang membawa manusia pada tingkat kesadaran yang kritis. Apabila sistem kendalinya berfungsi dengan baik, ia mampu mencapai puncaknya seperti berpaham rasionalisme. Kepribadian humanis bisa bernilai baik menurut ukuran manusia, sebab paham ini mengakui kekuatan, kebebasan, kemerdekaan hak-hak asasi manusia secara mutlak. Namun kepribadian humanis bisa bernilai buruk menurut konsepsi kepribadian Islam, sebab paham ini telah melupakan perjanjian Tuhan yang telah ditetapkan di alam arwah. Kepribadian humanis adalah kepribadian yang lupa diri, tidak tahu diri bahkan sesat diri36. Oleh karena kedudukannya yang tidak stabil ini maka Ibnu Qayim Al-Jauziy membagi kepribadian lawwamah menjadi dua, yaitu 1). Kepribadian lawwamah malumah, yaitu kepribadian lawwamah yang bodoh dan zalim, 2) Kepribadian lawwamah ghayr malumah, yaitu kepribadian yang mencela atas perbuatan yang buruk dan berusaha memperbaikinya ${ }^{37}$.

\section{c) Kepribadian Muthmainnah (nafs al-mutmainnah)}

Kepribadian muthmainnah adalah kepribadian yang telah diberikan kesempurnan nur qalbu sehingga dapat meninggalkan sifat-sifat tercela dan menumbuhkan sifat-sifat terpuji. Kepribadian ini selalu berorientasi ke komponen qalbu untuk mendapatkan kesucian dan menghilangkan segala pikiran dan perbuatan tercela sehingga dirinya menjadi tenang 38 .

Kepribadian muthmainnah bersumber dari qalbu manusia, sebab hanya qalbu yang dapat merasakan thuma'ninah (QS Al-Ra'd 13:28). Sebagai komponen yang bernatur ilahiah qalbu selalu cenderung pada ketenangan dalam beribadah, mencintai, bertaubat, bertawakal dan mencari ridha Allah Swt.

36 Netty Hartati, dkk, 2004, Islam dan Psikologi, Rajawali Pers, Jakarta,. Hlm. 168

37 Harun Nasution, 1995, Falsafat dan Mistisme dalam Islam, Bulan Bintang, Jakarta

38 Abd Al-Razzaq Al-Kalasyaniy, op.cit., hlm 116 
Kepribadian muthmainnah merupakan kepribadian supra kesadaran manusia, hal tersebut dikarenakan kepribadian ini merasa tenang dalam menerima keyakinan fitriah (fithrah al-munazzalah). Penerimaan ini tidak bimbang atau ragu-ragu seperti yang dialami oleh kepribadian lawwamah, tetapi penuh dengan keyakinan. Oleh karena itu, ia cenderung menggunakan metode dawk (cita rasa) dan 'ain al-bashirah (mata bathin) dalam menerima sesuatu sehingga ia merasa yakin dan tenang dalam menghadapi pilihan-pilihan.

Qalbu (yang mendominasi kepribadian muthmainnah) mampu mencapai pengetahuan (ma'rofah) melalui daya cita rasa (dawk) dan kasyf (terbukanya tabir misteri yang menghalangi tabir penglihatan manusia) ${ }^{39}$

Sedangkan Ibn Khaldun menyatakan dalam Muqaddimat bahwa ruh qalbu itu disinggahi oleh ruh akal yang secara substansial mampu mengetahui apa saja di alam amar, sebab ia berpotensi demikian. Dengan kekuatan dan kesucia daya qalbu maka manusia akan mampu memperoleh wahyu (pengetahuan) dan ilham dari Tuhan. Wahyu diberikan pada para nabi, sedangkan ilham diberikan pada manusia. Kebenaran pengetahuan ini bersifat supra-rasional, sehingga terkadang ia tidak bisa diterima oleh akal. Pengetahuan yang dapat ditangkap oleh akal seharusnya dapat pula ditangkap oleh qalbu, sebab qalbu sebagian dayanya ada yang digunakan untuk berakal, sebaliknya pengetahuan yang diterima oleh qalbu belum tentu dapat diterima oleh akal, sebab kemampuan akal (otak) di bawahnya.

\section{F. ISLAM MEMANDANG KEMATANGAN KARIR}

Istilah karier memiliki makna yang berbeda-beda tergantung dari sudut pandangnya masing-masing. Namun demikian, terdapat kesamaan bahwa masalah karier tidak dapat dilepaskan dengan aspek perkembangan, pekerjaan, jabatan, dan proses pengambilan keputusan. Atas dasar ini, untuk memperoleh pemahaman yang lebih luas dan komprehensif tentang hakekat karier, bagian ini akan

39 Abu Hamid Muhammad Al-Ghazali, Al-Munqidz, op. Cit., hlm. 205 
menjelaskan tentang konsep dasar karier, teori-teori perkembangan karier, serta implikasinya terhadap konseling.

Manusia sebagai ciptaan Allah Swt tidak mungkin lepas dari tuntutannya sebagai makhluk yang memiliki tugas-tugas penciptaannya. Sebagaimanapun banyaknya pengetahuan manusia yang didapat lewat akal pikiran tidak dapat dipisahkan dari qalbu sehingga cenderung ada potensi ketidakutuhan dalam melihat teori-teori psikologi mengenai manusia yang dapat menyebabkan kesalahan fatal dalam kelanjutan implementasinya .

Dalam konteks kematangan karir, individu yang memilih pekerjaan berdasakan pada rasa puas, vacational satisfication seringkali belum terselesaikan problemnya. Segala macam karir tidak dapat dipisahkan dengan nilainilai Islam karena semua pekerjaan, karir, jabatan ditujukan untuk mengabdi dan mencari keridhoan Tuhan.

Dan (ingatlah) ketika Tuhanmu berfirman kepada para malaikat, "Aku hendak menjadikan khalifah di muka bumi. (QS. 2:30) $)^{40}$

Islam memandang kematangan karir sebagai suatu hal yang sangat penting sehingga banyak sekali referensi yang bisa diambil dari Al Qur'an sebagai acuan bagi kita untuk memahami kematangan karir remaja. Antara lain sebagai berikut :

a. Allah swt menjamin bahwa setiap makhluk pasti diberi fasilitas kehidupan.

Dan sungguh, Kamilah yang menghidupkan dan mematikan dan kami (pulalah) yang mewarisi. (QS 15:23)

b. Allah swt mengakui derajat dan martabat manusia, serta telah menyediakan fasilitas selengkapnya agar manusia hidup secara bermartabat.

Dan sungguh, kami telah memuliakan anak cucu Adam, dan kami angkut mereka di darat dan di laut, dan Kami beri

40 Ibid; hal 89 
mereka rezeki yang baik-baik dan kami lebihkan mereka di atas banyak makhluk yang Kami ciptakan dengan kelebihan yang serpurna. (QS. 17:70)

c. Ada persamaan hak berkarir antara pria dan wanita, semua akan diberi pahala yang sama saat mampu menunaikan kebajikan.

Dan barangsiapa mengerjakan amal kebajikan, baik laki-laki maupun perempuan sedang dia beriman, maka mereka itu akanmasuk ke dalam surga dan mereka tidak didzalimi sedikit pun. (QS. 4:124)

d. Menekuni suatu karir kerja memerlukan ilmunya.

Dan jangan kamu mengikuti sesuatu yang tidak kamu ketahui, karena pendengaran, penglihatan, dan hati nerani, semua itu akan diminta pertanggungjawabannya. (QS. $17: 36)$

e. Karir ditujukan juga untuk menggapai kesejahteraan dan menolak petaka.

Wahai orang-orang yang beriman! Periharalah dirimu dan keluargamu dari apai neraka yang bahan bakarnya adalah manusia dan batu; penjaganya malaikat-malaikat yang kasar, dank eras yang tidak durhaka kepada Allah terhadap apa yang Dia perintahkan kepada mereka dan selalu mengerjakan apa yang diperintahkan. (QS, 66:6)

f. Allah telah menganugrahkan segala yang ada di bumi ini untuk fasilitas karir.

Dialah (Allah) yang menciptakan segala apa yang ada di bumi untukmu kemudian Dia menuju ke langit, lalu Dia menyempurnakannya menjadi tujuh langit. Dan Dia Maha Mengetahui segala sesuatu. (QS. 2:29)

g. Hal fitrahi yang berkenaan dengan dorongan untuk berkeluarga, memiliki usaha dijamin oleh Allah Swt. 
Dijadikan terasa indah dalam pandangan manusia cinta terhadap apa yang diinginkan, berupa perempuan-perempuan, anak-anak, harta benda yang bertumpuk dalam bentuk emas dan perak, kuda pilihan, hewan ternak, dan sawh lading. Itulah kesenangan hidup di dunia, dan di sisi Allah-lah tempat kembali mereka. (QS. 3:14)

\section{Daftar Pustaka}

Abraham H. Maslow. 1993. Motivasi dan Kepribadian. Jakarta: PT. Pustaka Binawan Presindo

Angelis, De Barbara. 2003. Confidence Sumber Sukses Dan Kemandirian. Jakarta: Gramedia Pustaka Utama.

Bandura, A. (1997). Self efficacy: The exercise of control. New York: Freeman.

Dede Rahmat Hidayat. 2005. Teori Dan Aplikasi Psikologi Kepribadian dalam Konseling. Yogyakarta: Ghalia Indonesia

Fasikhah, S.S. 1994. Peranan kompetensi sosial pada T.L koping remaja akhir. Tesis. Yogyakarta: Program P.S UGM Yogyakarta.

Gonzalez, Manuel Alvarez. 2008. Career Maturity: A Priority for Secondary Education. Electronic Journal of Research in Educatonal Psychologi (No. 16 Vol. 6 (3). 2008). p. 749-772.

Hasan, B. 2006. Career Maturity of Indians Adolescents as A Function of Self Concept, Vocational Aspiration and Gender. Journal of the IndianAcademy of Applied Psychology (No. 2 Vol. 32 February 2006).

Hurlock, Elizabeth, B. 1993. Perkembangan Anak, Erlangga. Jakarta: Erlangga.

Iswidharmanjaya, Derry, dkk. 2004. Suatu Hari Menjadi Lebih Percaya Diri. Jakarta: Elex Media Komputindo. 
Levinson, Edward $M$ et. al. 1998. Six Approaches to the Assessment of Career Maturity. Journal of Counseling and Development (Vol.76 Iss.4 Fall 1998).

Mujiadi. 2003. Psikologi Perkembangan. Yogyakarta: Gadjah Mada University Press.

Netty Hartati, dkk, 2004, Islam dan Psikologi, Jakarta : Rajawali Pers

Powell, Darrell F and Luzzo, Darrell Anthony. 1998. Evaluating Factors Associated with the Career Maturity of High School Students. The Career Development Quarterly (Vol. 47 Iss. 2 December 1998). p. 145.

Reivich \& Shatté. 2002. The Resilience Factor: 7 Essential Skills for OvercomingLife's Inevitable Obstacles. New York City: Broadway Books.

Stoltz, Paul Gordon. 2000. Mengubah Hambatan Menjadi Peluang. Jakarta: PenerbitGrasindo.

Thantaway. 2005. Kamus Bimbingan dan Konseling. Jakarta: Grasindo.

Thursan hakim. 2005. Belajar Secara Efektif. Jakarta: puspa swara. Tri Muji Ingarianti. 2009. Hubungan Antara Adversity Quotient Dengan Kematangan Karir Pada Remaja. Laporan Penelitian. UMM Malang.

W. S Winkel \& Sri Hastuti. 2005. Bimbingan dan Konseling di Institusi Pendidikan. Yogyakarta: FKIP Universitas Sanata Dharma. 
114 | Bimbingan Penyuluhan Islam, Vol. 1, No. 1 Januari-Juni 2019 